\title{
Właściwości połączeń spawanych ze stali dwufazowych - DP
}

\section{Properties of dual-phase (DP) steels welded joints}

\section{Streszczenie}

W pracy przedstawiono wyniki analizy wartości równoważnika węgla $C_{e}$ stali dwufazowych DP ze stalami wielofazowymi CP i TRIP, konwencjonalnymi o wysokiej granicy plastyczności do obróbki plastycznej na zimno $L A D+B D+Y D$ i o podwyższonej granicy plastyczności w stanie ulepszonym cieplnie. Przedstawiono również wyniki badań metalograficznych i wybranych właściwości mechanicznych złączy spawanych metodą spawania GTAW stali dwufazowych: DP600Z140+M DP800Z140+M i DP1000Z140+M.

\section{Charakterystyka stali DP i problemy jej spawalności}

Zaawansowane stale o wysokiej wytrzymałości (AHSS - Advanced High Strength Steel) dzięki korzystnym właściwościom mechanicznym w odniesieniu do gęstości umożliwiają wyraźne zmniejszenie masy konstrukcji.

Analizowana stal stopowa jakościowa Litec DP Ruukki zaliczana jest do stali dwufazowych do obróbki plastycznej na zimno wg PN-EN 10346 [8]. Gatunki stali sklasyfikowano w normie według ich wzrastającej minimalnej wytrzymałości na rozciąganie $R_{m}$ (tabl. I i II).

Mikrostruktura stali dwufazowych DP składa się z 30 $\div 70 \%$ martenzytu w osnowie drobnoziarnistego, sferoidalnego ferrytu i $1 \div 5 \%$ metastabilnego austenitu szczątkowego. Warunkuje to wysoką wytrzymałość na rozciąganie do $1180 \mathrm{MPa}$ (Arcelor Mittal Dual Phase $1180 \mathrm{HY}$ ) przy wydłużeniu względnym $A_{80}$ do $27 \%$. Mikrostruktura stali DP najczęściej powstaje w wyniku szybkiego nagrzania cienkich blach po walcowaniu na zimno do zakresu między $A_{1}$ a $A c_{3}$ i kontrolowanym

Mgr inż. Sławomir Krajewski, prof. dr hab. inż. Jerzy Nowacki - Zachodniopomorski Uniwersytet Technologiczny w Szczecinie. chłodzeniu mgłą wodno-powietrzną do temperatury otoczenia (rys. 1). Drobne ziarno ferrytu uzyskiwane jest przez opóźnienie i zahamowanie rekrystalizacji austenitu w obecności takich mikrododatków stopowych jak: Al, V, Ti i Nb. PN-EN 10346 [8] metodę produkcji

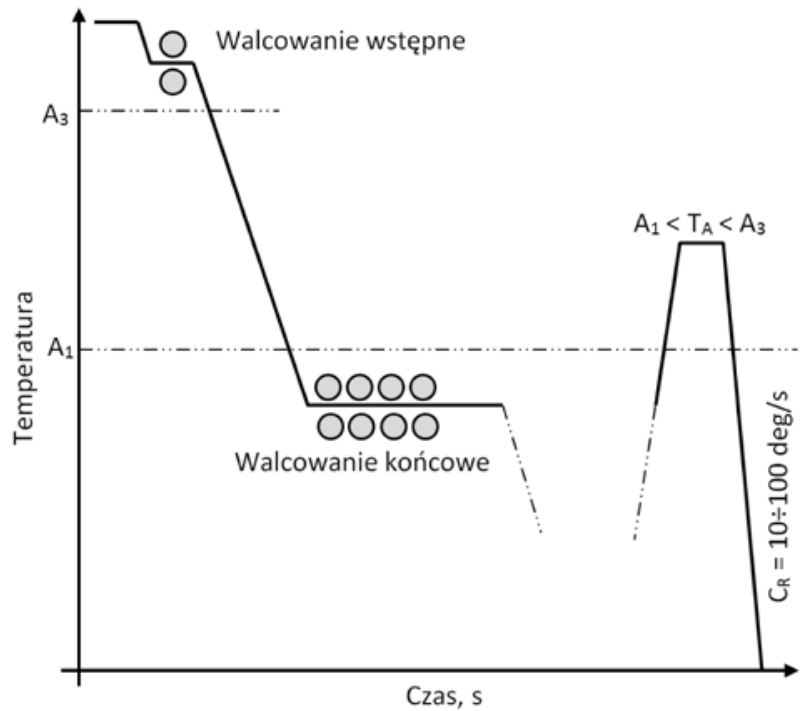

Rys. 1. Schemat obróbki termomechanicznej stali Litec 600DP, 800DP i 1000DP użytych w eksperymencie, $T_{A}$ - temperatura częściowej austenityzacji, $C_{R}$ - szybkość chłodzenia [5]

Fig. 1. Litec 600DP, $800 \mathrm{DP}$ i 1000DP steel thermo mechanical processing diagram used in the experiment, $\mathrm{T}_{\mathrm{A}}$ - partial austenitizing temperature, $C_{R}-$ cooling rate [5] 
stali pozostawia w gestii wytwórcy, przy czym uzyskanie drobnoziarnistej struktury dwufazowej ferrytyczno-martenzytycznej wymaga stosowania optymalnego zakresu temperatury nagrzewania i przebiegu chłodzenia. Regulowane walcowanie z kolei pozwala obniżyć temperaturę walcówki przy zapewnieniu wymaganego zgniotu. W temperaturze pomiędzy $\mathrm{Ar}_{3}$ i $\mathrm{Ar}_{1}$ następuje przyspieszone chłodzenie.

Stal AHSS znajduje zastosowanie w przemyśle motoryzacyjnym m.in. na: ramy i belki poprzeczne, belki pionowe, belki wzmocnienia bocznego oraz elementy bezpieczeństwa, najczęściej zgrzewane oporowo [1]. W ostatnich latach prowadzone są badana dotyczące spawalności tych stali.

Wytwórcy stali dwufazowych dopuszczają stosowanie wszystkich metod spawania łukowego, zalecając zwłaszcza metody MIG, TIG i PAW oraz zgrzewanie elektryczne oporowe. Metody te są szczególnie pożądane w przemyśle motoryzacyjnym, ze względu na małe rozmiary i grubość elementów wykonywanych z tych stali oraz układanie lokalnych spoin nośnych przenoszących wysokie obciążenia. Ze względów estetycznych wymagana jest z kolei wąska spoina oraz zachowanie wysokiej czystości i jakości spoin.
Do spawania stosowane są materiały dodatkowe gwarantujące uzyskanie wyższej wytrzymałości na rozciąganie złącza niż materiału podstawowego, jednak np. w przypadku stali DP800 i DP1000 wytrzymałość na rozciąganie spoiny może być niższa niż materiału rodzimego, wobec braku dostępnych materiałów o tak wysokim $\mathrm{R}_{\mathrm{m}}[2,4,6]$.

Dla stali DP pokrytych powłoką cynkową zalecanymi metodami spawania są spawanie łukowe i wiązką laserową.

\section{Równoważnik węgla $C_{\mathrm{e}}$ stali DP na tle innych stali}

W celu oceny spawalności stali o wysokiej wytrzymałości porównano wartości równoważnika węgla $C_{\text {e }}$ wg równania (1) stali dwufazowych DP (rys. 2) ze stalami wielofazowymi CP (Complex-phase) (rys. 3), typu TRIP (Transformation Induced Plasticity) (rys. 4), stalami konwencjonalnymi używanymi w przemyśle motoryzacyjnym o wysokiej granicy plastyczności do

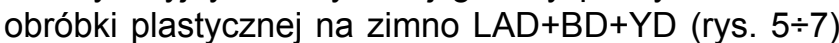

Tablica I. Skład chemiczny (analiza wytopowa) stali dwufazowych do obróbki na zimno wg PN-EN 10346 [8]

Table I. The chemical composition of dual-phase steels for cold forming acc. to PN-EN 10346 [8]

\begin{tabular}{|c|c|c|c|c|c|c|c|c|c|c|c|c|}
\hline \multicolumn{3}{|c|}{ Oznaczenie } & \multicolumn{10}{|c|}{ Skład chemiczny, \% mas. } \\
\hline \multicolumn{2}{|c|}{ Gatunek stali } & \multirow{2}{*}{$\begin{array}{l}\text { Symbol rodzaju na- } \\
\text { niesionej powłoki** }\end{array}$} & \multirow{2}{*}{ C max. } & \multirow{2}{*}{ Si max. } & \multirow{2}{*}{ Mn max. } & \multirow{2}{*}{$P$ max. } & \multirow{2}{*}{$S$ max. } & \multirow{2}{*}{ Al całkowite } & \multirow{2}{*}{$\begin{array}{l}\mathrm{Cr}+\mathrm{Mo} \\
\max .\end{array}$} & \multirow{2}{*}{$\begin{array}{l}\mathrm{Nb}+\mathrm{Ti} \\
\max .\end{array}$} & \multirow{2}{*}{$V$ max. } & \multirow{2}{*}{ B max. } \\
\hline Znak stali* & Numer stali & & & & & & & & & & & \\
\hline HCT450X & 1.0937 & \multirow{3}{*}{$+\mathrm{Z},+\mathrm{ZF},+\mathrm{ZA}$} & \multirow{2}{*}{0,14} & \multirow{6}{*}{0,80} & \multirow{2}{*}{2,00} & \multirow{6}{*}{0,080} & \multirow{6}{*}{0,015} & \multirow{6}{*}{$\leq 2,00$} & \multirow{6}{*}{1,00} & \multirow{6}{*}{0,15} & \multirow{6}{*}{0,20} & \multirow{6}{*}{0,005} \\
\hline HCT500X & 1.0939 & & & & & & & & & & & \\
\hline HCT600X & 1.0941 & & \multirow{2}{*}{0,17} & & \multirow{2}{*}{2,20} & & & & & & & \\
\hline HDT580X & 1.0936 & $+\mathrm{Z},+\mathrm{ZF}$ & & & & & & & & & & \\
\hline HCT780X & 1.0943 & \multirow{2}{*}{$+\mathrm{Z},+\mathrm{ZF},+\mathrm{ZA}$} & 0,18 & & \multirow{2}{*}{2,50} & & & & & & & \\
\hline HCT980X & 1.0944 & & 0,23 & & & & & & & & & \\
\hline
\end{tabular}

* $\mathrm{H}$ - wyroby płaskie ze stali o wysokiej granicy plastyczności do obróbki plastycznej na zimno, C - wyroby walcowane na zimno, D - wyroby walcowane na gorąco, $T X X X$ - minimalna wytrzymałość na rozciąganie $R_{m} X X X, M P a, X-$ stal dwufazowa

${ }^{\star *}+Z,+Z F,+Z A-+Z-$ ogniowe powlekanie cynkiem, +ZF - ogniowe powlekanie stopem cynk-żelazo, +ZA - ogniowe powlekanie stopem cynk-aluminium

Tablica II. Właściwości mechaniczne stali dwufazowych do obróbki plastycznej na zimno wg PN-EN 10346 [8]

Table II. The mechanical properties of dual-phase steel for cold forming acc. to PN-EN 10346 [8]

\begin{tabular}{|c|c|c|c|c|}
\hline \multirow{2}{*}{\multicolumn{2}{|c|}{$\begin{array}{l}\text { Oznaczenie } \\
\text { Gatunek stali }\end{array}$}} & \multicolumn{3}{|c|}{ Właściwości mechaniczne } \\
\hline & & \multirow{2}{*}{$\begin{array}{l}\text { Umowna granica pla- } \\
\text { styczności } R_{p 0,2}, M P a\end{array}$} & \multirow{2}{*}{$\begin{array}{l}\text { Wytrzymałość na rozcią- } \\
\text { ganie min. } R_{m}, M P a\end{array}$} & \multirow{2}{*}{$\begin{array}{l}\text { Wydłużenie min. } \\
A_{80}^{a, b}, \%\end{array}$} \\
\hline Znak stali & Numer stali & & & \\
\hline HCT450X & 1.0937 & $260-340$ & 450 & 27 \\
\hline HCT500X & 1.0939 & $300-380$ & 500 & 23 \\
\hline HCT600X & 1.0941 & $340-420$ & 600 & 20 \\
\hline HDT580X & 1.0936 & $330-460$ & 580 & 19 \\
\hline HCT780X & 1.0943 & $450-560$ & 780 & 14 \\
\hline НСТ980X & 1.0944 & $600-750$ & 980 & 10 \\
\hline
\end{tabular}


oraz stalami o podwyższonej granicy plastyczności w stanie ulepszonym cieplnie np. S960Q (rys. 8).

$$
C_{e}=C+\frac{M n}{6}+\frac{C r+M o+V}{5}+\frac{N i+C u}{15}
$$

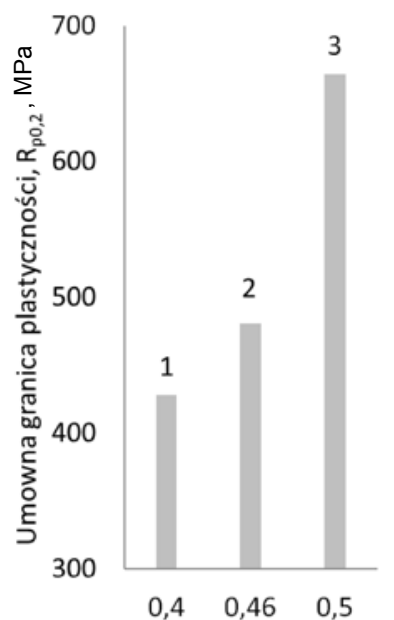

Równoważnik węgla, $C_{e} \%$

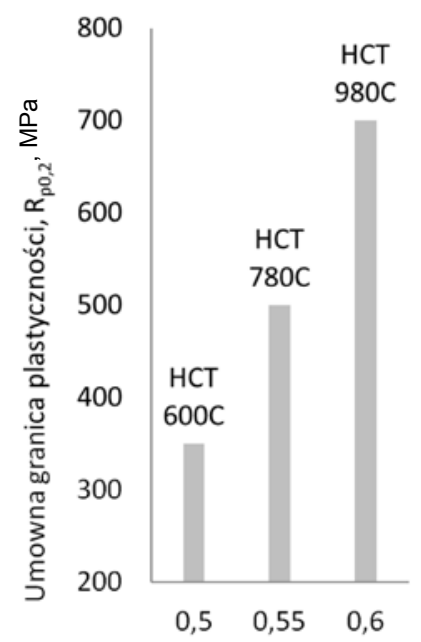

Równoważnik węgla, $C_{e} \%$

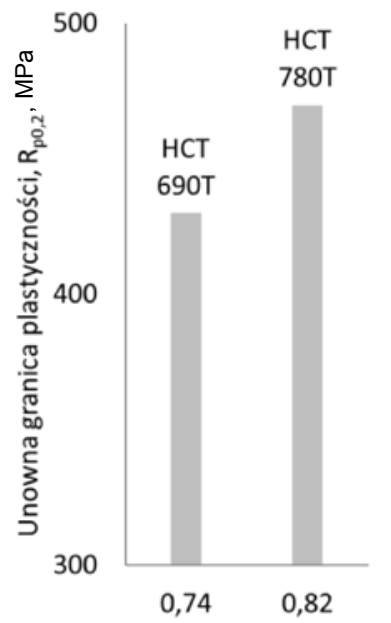

Równoważnik węgla, $C_{e} \%$
Rys. 2. Porównanie wartości równoważnika węgranicy plastyczności $R_{\text {po }}$ dla stali dwufazowych $\mathrm{DP}$; 1 - Litec 600DP, 2 - Litec 800DP, 3 - Litec 1000DP

Fig. 2. Comparison of the carbon equivalent $\mathrm{C}_{\mathrm{e}}$ and yield strength $R_{e H}$ for dual - phase steel; 1 - Litec 600DP, 2 - Litec 800DP, 3 - Litec 1000DP

Rys. 3. Porównanie wartości równoważnika węgla $\mathrm{C}_{\mathrm{e}}$ względem umownej granicy plastyczności $R_{p 02}$ dla stali wielofazowych $\mathrm{CP}$

Fig. 3. Comparison of the carbon equivalent $\mathrm{C}_{e}$ and yield strength $R_{\text {eн }}$ for complex phase steel

Rys. 4. Porównanie wartości równoważnika węgla $C_{\text {e }}$ względem umownej granicy plastyczności $R_{\mathrm{p} 0,2}$ dla stali typu TRIP (umacniane odkształceniem plastycznym) Fig. 4. Comparison of the carbon equivalent $\mathrm{C}_{e}$ and yield strength $R_{e H}$ for TRIP steel gla $C_{e}$ względem umownej

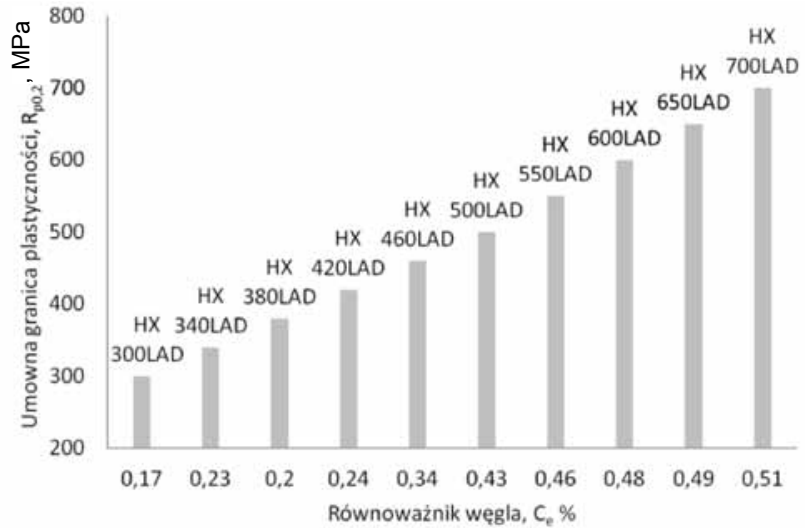

Rys. 5. Porównanie wartości równoważnika węgla $C_{e}$ względem umownej granicy plastyczności $R_{\mathrm{p0}, 2}$ dla stali niskostopowej/mikrostopowej LAD

Fig. 5. Comparison of the carbon equivalent $C_{e}$ and yield strength $R_{\text {eH }}$ for LAD steel

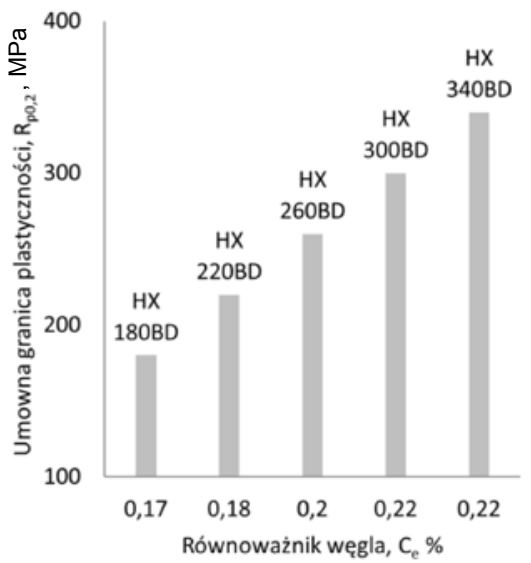

Rys. 6. Porównanie wartości równoważnika węgla $C_{\text {e }}$ względem umownej granicy plastyczności $R_{p 0,2}$ dla stali utwardzanej niskotemperaturowo/stal bake-hardening $\mathrm{BD}, 2$

Fig. 6. Comparison of the carbon equivalent $C_{e}$ and yield strength $R_{e H}$ for bake-hardening steel

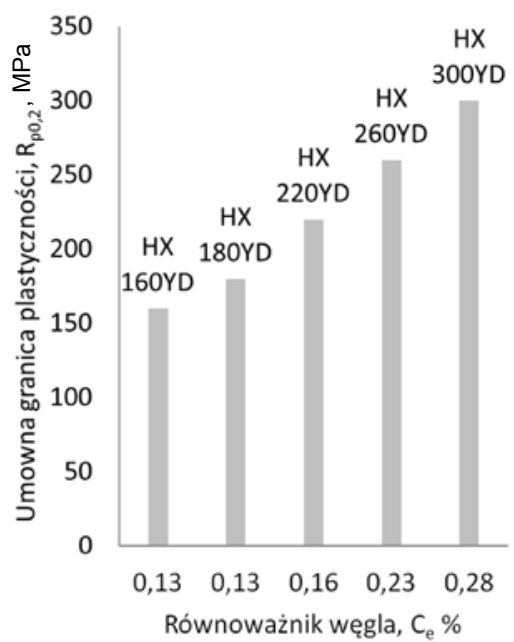

Rys. 7. Porównanie wartości równoważnika węgla $C_{e}$ względem umownej granicy plastyczności $R_{\text {iz }}$ dla stali tzw. IF bez atomów w położeniach międzywęzłowych $\mathrm{YD}, 2$

Fig. 7. Comparison of the carbon equivalent $C_{e}$ and yield strength $\mathrm{R}_{\mathrm{eH}}$ for IF steel 


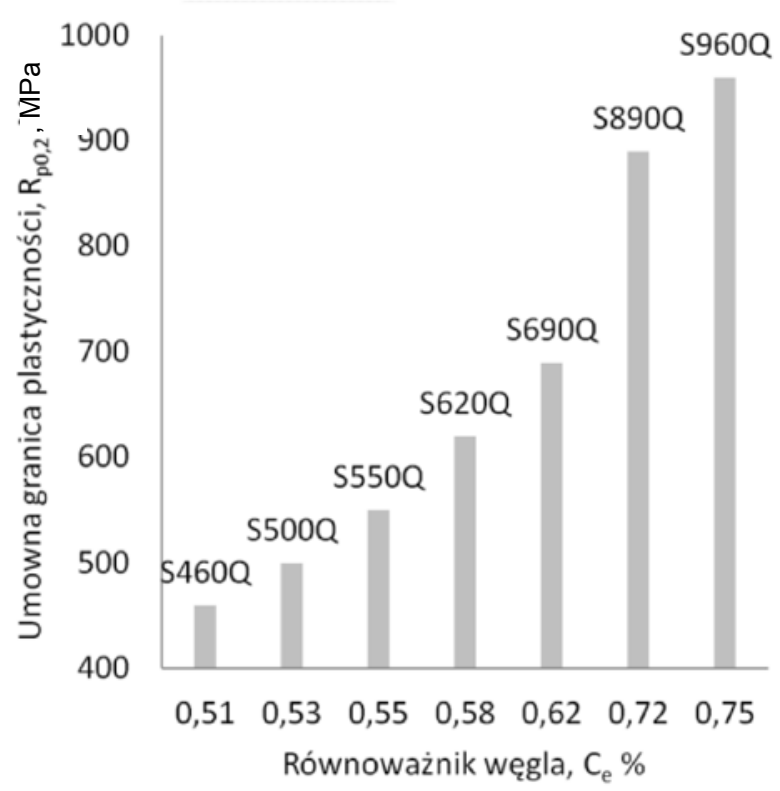

Rys. 8. Porównanie wartości równoważnika węgla $C_{e}$ względem umownej granicy plastyczności $R_{\mathrm{p} 0,2}$ dla stali o podwyższonej granicy plastyczności w stanie ulepszonym cieplnie

Fig. 8. Comparison of the carbon equivalent $C_{e}$ and yield strength $R_{e H}$ for of high yield strength structural steels in the quenched and tempered condition steel

Stale dwufazowe DP, mając wyższą o $60 \div 90 \%$ granicę plastyczności od niestopowych stali konstrukcyjnych zwykłej jakości przeznaczonych do spawania cechują się umiarkowaną wartością równoważnika węgla $\mathrm{C}_{\mathrm{e}}$, sugerującą ich dobrą spawalność metalurgiczną.

\section{Próby spawania stali DP}

Badania wykonano w celu określenia wpływu metody łączenia TIG i PAW na parametry wytrzymałościowe złącza.

Badania spawalności przeprowadzono na stali Litec 600DP, Litec 800DP i Litec 1000DP firmy Ruukki, których skład chemiczny określony za pomocą spektrometru jarzeniowego LECO GDS 500A przedstawiono w tablicy III.

Statyczną próbę rozciągania zastosowanych do spawania blach o grubości $1,2 \mathrm{~mm}$ wykonano na maszynie Instron 5585H (tabl. IV). Przedstawiono uśrednione wartości z 3 próbek pobranych wzdłuż kierunku walcowania.

Fotografie mikrostruktury stali Litec 600DP, 800DP i 1000DP użytych do wykonania złącza spawanego przedstawiono odpowiednio na rysunkach $9 \div 11$. Obserwację mikrostruktury prowadzono na zgładach metalograficznych trawionych $3 \%$ Nitalem przy zastosowaniu elektronowego mikroskopu skaningowego SEM JOEL JSM-6100. Objętość względną faz w mikrostrukturze określono za pomocą komputerowej analizy obrazu w systemie NIS Elements 3.1.

Porównaniu poddano przygotowane na I bez odstępu doczołowe złącza blach o grubości $1,2 \mathrm{~mm}$ spawane $z$ pełnym przetopem bez materiału dodatkowego metodą TIG i PAW w pozycji podolnej. Jako gaz osłonowy stosowano Argon 5.0 wg PN-EN ISO 14175 [10]. Możliwymi do stosowania materiałami dodatkowymi są te, które są przeznaczone do spawania stali niskostopowych, np.: AWS A5.28 ER 100S-G, AWS A5.28 ER 11XS-X, AWS A5.28 ER 12XS-X, DIN SGNiMoCr2 wg PN-EN ISO 16834 [13]. Parametry spawania plazmowego (PAW) techniką z jeziorkiem

Tablica III. Skład chemiczny zastosowanych w badaniach stali dwufazowych Ruukki Table III. The chemical composition used in the studies of dual-phase steel Ruukki

\begin{tabular}{|c|c|c|c|c|c|c|c|c|c|c|c|c|}
\hline \multicolumn{3}{|c|}{ Oznaczenie } & \multicolumn{10}{|c|}{ Skład chemiczny, \% mas. } \\
\hline \multicolumn{2}{|c|}{ Gatunek stali } & \multirow{2}{*}{$\begin{array}{c}\text { Symbol rodzaju } \\
\text { naniesionej powłoki }\end{array}$} & \multirow{2}{*}{ C } & \multirow{2}{*}{ Si } & \multirow{2}{*}{$\mathrm{Mn}$} & \multirow{2}{*}{$\mathrm{P}$} & \multirow{2}{*}{$S$} & \multirow{2}{*}{$\begin{array}{c}\text { Al całko- } \\
\text { wite }\end{array}$} & \multirow{2}{*}{$\mathrm{Cr}+\mathrm{Mo}$} & \multirow{2}{*}{$\mathrm{Nb}+\mathrm{Ti}$} & \multirow{2}{*}{$\mathrm{V}$} & \multirow{2}{*}{ B } \\
\hline Znak stali & Znak stali & & & & & & & & & & & \\
\hline Litec 600DP & HCT600X & $\mathrm{Z} 140+\mathrm{M}^{*}$ & 0,09 & 0,21 & 1,87 & 0,0065 & 0,00 & 0,0273 & 0,0058 & 0,0023 & 0,0063 & 0,001 \\
\hline Litec 800DP & HCT780X & $\mathrm{Z} 140+\mathrm{M}^{*}$ & 0,13 & 0,27 & 1,88 & 0,0046 & 0,00 & 0,0304 & 0,0087 & 0,0017 & 0,01 & 0,001 \\
\hline Litec 1000DP & HCT980X & $\mathrm{Z} 140+\mathrm{M}^{*}$ & 0,15 & 0,22 & 1,80 & 0,0067 & 0,00 & 0,0292 & 0,176 & 0,0041 & 0,0118 & 0,001 \\
\hline
\end{tabular}

Tablica IV. Właściwości mechaniczne zastosowanych w badaniach stali dwufazowych Ruukki, wg badań własnych

Table IV. The mechanical properties used in the studies of dual-phase steel Ruukki, acc. to the own research

\begin{tabular}{|c|c|c|c|c|}
\hline \multirow{2}{*}{\multicolumn{2}{|c|}{$\begin{array}{l}\text { Oznaczenie } \\
\text { Gatunek stali }\end{array}$}} & \multicolumn{3}{|c|}{ Właściwości mechaniczne } \\
\hline & & \multirow{2}{*}{$\begin{array}{c}\text { Umowna granica } \\
\text { plastyczności } \mathrm{R}_{\mathrm{p0}, 2}, \mathrm{MPa}\end{array}$} & \multirow{2}{*}{$\begin{array}{l}\text { Wytrzymałość na } \\
\text { rozciąganie } R_{m}, M P a\end{array}$} & \multirow{2}{*}{ Wydłużenie $\mathrm{A}_{80}, \%$} \\
\hline Znak stali & Znak stali & & & \\
\hline Litec 600DP & HCT600X & $428-448$ & 694 & 22 \\
\hline Litec 800DP & HCT780X & $481-488$ & 845 & 16 \\
\hline Litec 1000DP & HCT980X & $664-675$ & 1030 & 11 \\
\hline
\end{tabular}




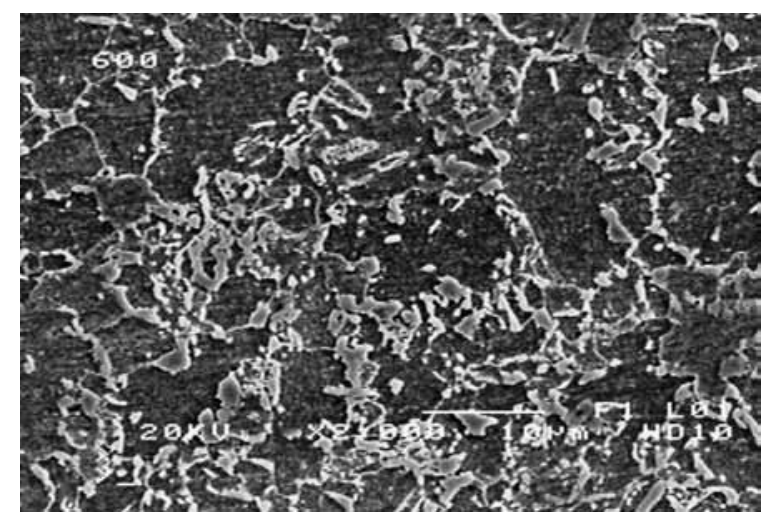

Rys. 9. Mikrostruktura stali 600DP. Objętość względna: ferrytu $~ 66 \%$, martenzytu $\sim 33 \%$, austenitu szczątkowego 1\%

Fig. 9. Microstructure of steel 600DP. The relative volume of: ferrite $-66 \%$, martensite $\sim 33 \%$ and retained austenite $\sim 1 \%$

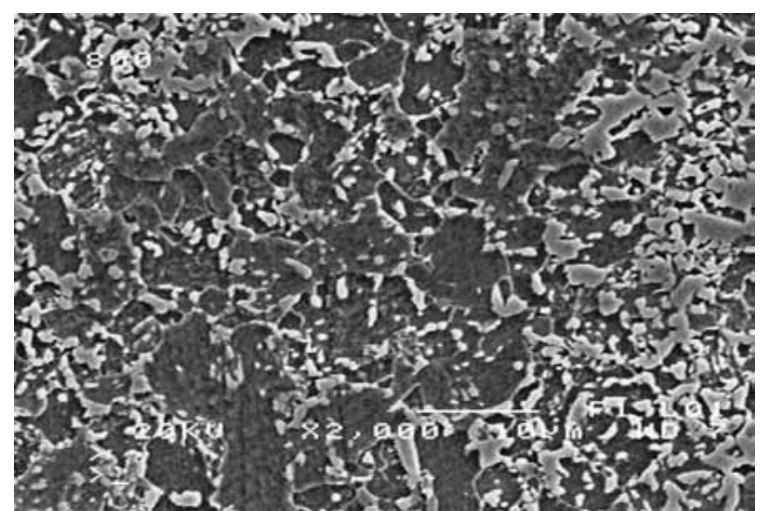

Rys. 10. Mikrostruktura stali 800DP. Objętość względna: ferrytu $\sim 55 \%$, martenzytu $\sim 44 \%$, austenitu szczątkowego $\sim 1 \%$

Fig. 10. Microstructure of steel 800DP. The relative volume of: ferrite $\sim 55 \%$, martensite $\sim 44 \%$ and retained austenite $\sim 1 \%$

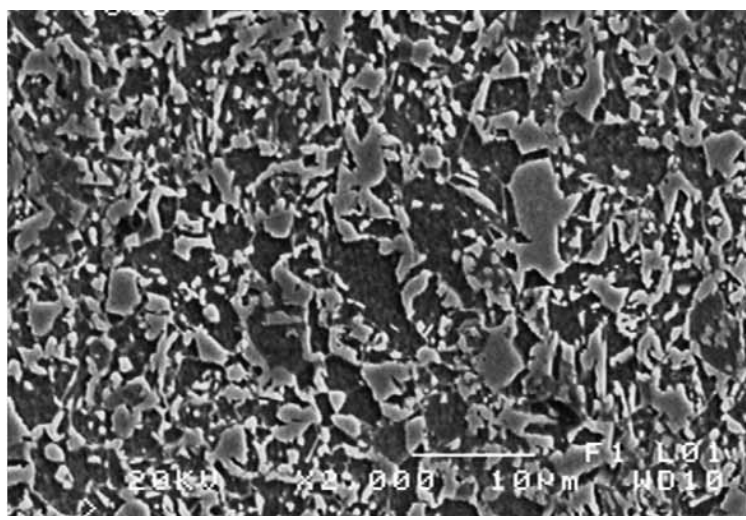

Rys. 11. Mikrostruktura stali 1000DP. Objętość względna: ferrytu $\sim 41 \%$, martenzytu wysepkowego $\sim 58 \%$, austenitu szczątkowego $\sim 1 \%$ Fig. 11. Microstructure of steel 1000DP. The relative volume of: ferrite $\sim 41 \%$, martensite $\sim 58 \%$ and retained austenite $\sim 1 \%$

Tablica V. Parametry spawania plazmowego PAW

Table V. PAW welding parameters

\begin{tabular}{|c|c|}
\hline Rodzaj i natężenie prądu, A & $30 \mathrm{DC}(-)$ \\
\hline Napięcie łuku, $\mathrm{V}$ & 68,6 \\
\hline Prędkość spawania, $\mathrm{mm} / \mathrm{s}$ & 2 \\
\hline Natężenie przepływu gazu plazmowego, I/min & $0,3 \div 0,5$ \\
\hline Natężenie przepływu gazu ochronnego, I/min & $4 \div 6$ \\
\hline Rodzaj i średnica elektrody wolframowej, $\mathrm{mm}$ & $\mathrm{d} 1,0, \mathrm{~W}+\mathrm{Th}$ \\
\hline Kształt i wymiary dyszy plazmowej, $\mathrm{mm}$ & $\mathrm{d} 11$ \\
\hline
\end{tabular}

Tablica VI. Parametry spawania TIG

Table VI. TIG welding parameters

\begin{tabular}{|c|c|}
\hline Rodzaj i natężenie prądu, A & $30 \mathrm{DC}(-)$ \\
\hline Napięcie łuku, $\mathrm{V}$ & 11,5 \\
\hline Prędkość spawania, $\mathrm{mm} / \mathrm{s}$ & 3 \\
\hline Natężenie przepływu gazu ochronnego, I/min & $4 \div 6$ \\
\hline Rodzaj i średnica elektrody wolframowej, $\mathrm{mm}$ & $\mathrm{d} 1,6 \mathrm{~W}+\mathrm{Th}$ \\
\hline
\end{tabular}

spoiny urządzeniem EWM Microplasma 50 zawarto w tablicy $\mathrm{V}$, natomiast spawania elektrodą nietopliwa w osłonie gazu obojętnego na urządzeniu ESAB Origo TA24 (TIG) w tablicy VI.

\section{Badania złączy}

Ocenę złączy przeprowadzono na podstawie:

- badań nieniszczących wg PN-EN 571-1 [12],

- badań makro- i mikroskopowych wg PN-EN 1321 [9],

- statycznej próby rozciągania wg PN-EN ISO 4136 [14]

- badań mikrotwardości metodą Vickersa wg PN-EN ISO 9015-2 [15].

Badania penetracyjne wg PN-EN 571-1 [12] nie wykazały niezgodności - połączenia zakwalifikowano do poziomu akceptacji 1.

Wynik badań makroskopowych przedstawiono na przykładzie złącza spawanego wykonanego ze stali Litec 600DP na rysunku 12. W wyniku przeprowadzonych badań mikroskopowych zaobserwowano strukturę martenzytyczną w obszarze strefy wpływu ciepła. Przemiana martenzytyczna jest wynikiem dużej szybkości chłodzenia, która przechładza austenit do temperatury przemiany martenzytycznej Ms. W przypadku stali dwufazowych zawartość węgla jest niska (maksymalnie $0,23 \%$ dla stali HCT980X), a wraz ze spadkiem udziału węgla temperatura początku przemiany martenzytycznej wzrasta (dla stali Litec 600DP $0,09 \% \mathrm{C}, \mathrm{Ms}=440^{\circ} \mathrm{C}$ ) i dla zawartości węgla $0,23 \%$ wynosi ok. $390^{\circ} \mathrm{C}$ [5]. Cienkościenne połączenia wykonane $z$ blach o grubości 1,2 mm oddają szybko ciepło, a złożony skład chemiczny dodatkowo zwiększa

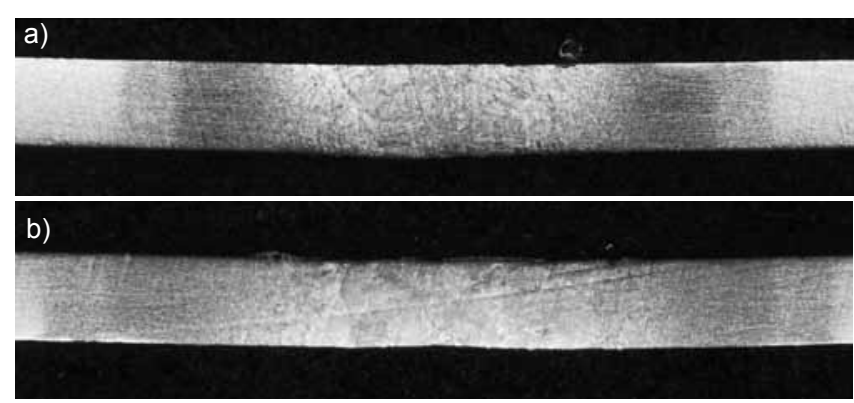

Rys. 12. Połączenie spawane ze stali Litec 600DP: a) spawane metodą PAW, b) spawane metodą TIG.

Fig. 12. Macrostructure of Litec 600DP steel joints: a) PAW welded, b) TIG welded. 

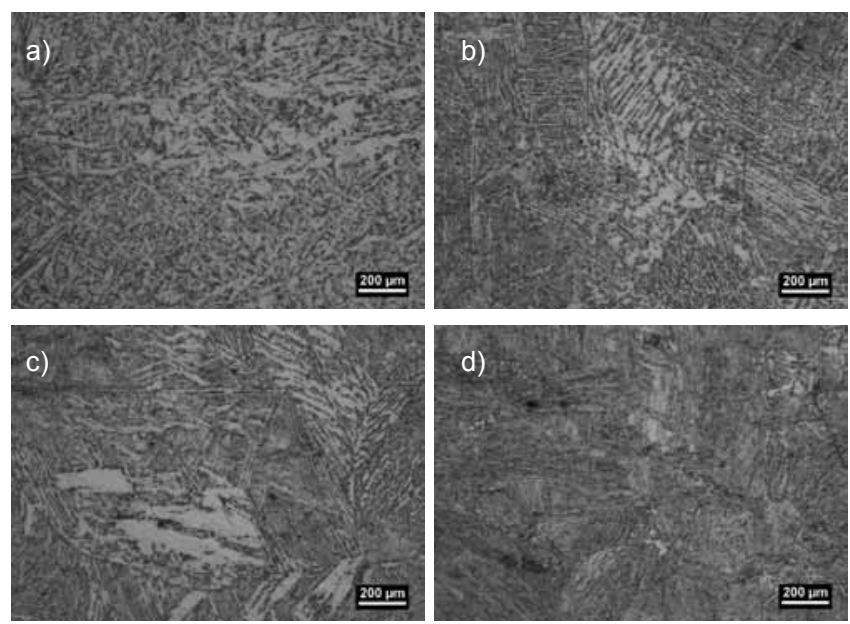

Rys. 13. Mikrostruktura złączy spawanych stali Litec 1000DP: a) spoina złącza spawanego metodą PAW (struktura ferrytyczno-perlityczna o cechach struktury Widmannstattena) b) SWC złącza spawanego metoda PAW c) spoina złącza spawanego metodą TIG (struktura Widmannstättena z wydzieleniami martenzytu, d) SWC złącza spawanego metodą TIG (gruboiglasty martenzyt)

Fig. 13. Mictrostructure of welded joints of Litec 1000DP steel: a) weld in PAW joint (ferritic - pearlitic structure with Widmannstätten features, b) HAZ in PAW joint, c) weld in TIG joint (Widmannstätten structure with isolated martensite, d) HAZ in TIG joint (coarse and acicular crystals of martensite)

Tablica VII. Wyniki badań statycznej próby rozciągania złączy spawanych

Table VII. The results of the static tensile test of welded joints

\begin{tabular}{|c|c|c|c|}
\hline \multicolumn{2}{|c|}{ Oznaczenie } & \multicolumn{2}{c|}{ Właściwości mechaniczne } \\
\hline Gatunek stali & $\begin{array}{c}\text { Umowna granica } \\
\text { plastyczności } \mathrm{R}_{\mathrm{p} 0,2} \\
\mathrm{MPa}\end{array}$ & $\begin{array}{c}\text { Wytrzymałość } \\
\text { na rozciąganie } \\
\mathrm{R}_{\mathrm{m}}, \mathrm{MPa}\end{array}$ \\
\hline Litec 600DP & PAW & $377-405$ & 615 \\
\hline Litec 800DP & PAW & $461-484$ & 820 \\
\hline Litec 1000DP & PAW & $636-647$ & 1009 \\
\hline Litec 600DP & TIG & $371-384$ & 607 \\
\hline Litec 800DP & TIG & $456-469$ & 806 \\
\hline Litec 1000DP & TIG & $611-627$ & 1002 \\
\hline
\end{tabular}

hartowność, co przyczynia się do powstania struktury martenzytycznej. Przykładowe, obserwowane mikrostruktury przedstawiono na rysunku 13.

Wyniki statycznej próby rozciągania złączy zawarto w tablicy VII. Obserwowany jest wzrost wytrzymałości złącza spawanego wraz ze wzrostem wytrzymałości na rozciąganie materiału rodzimego.

Wyniki pomiarów twardości HV10 złączy spawanych przedstawiono na rysunku 14. Wzrost twardości złącza spawanego ze stali Litec 1000DP do poziomu 431 HV10 a)
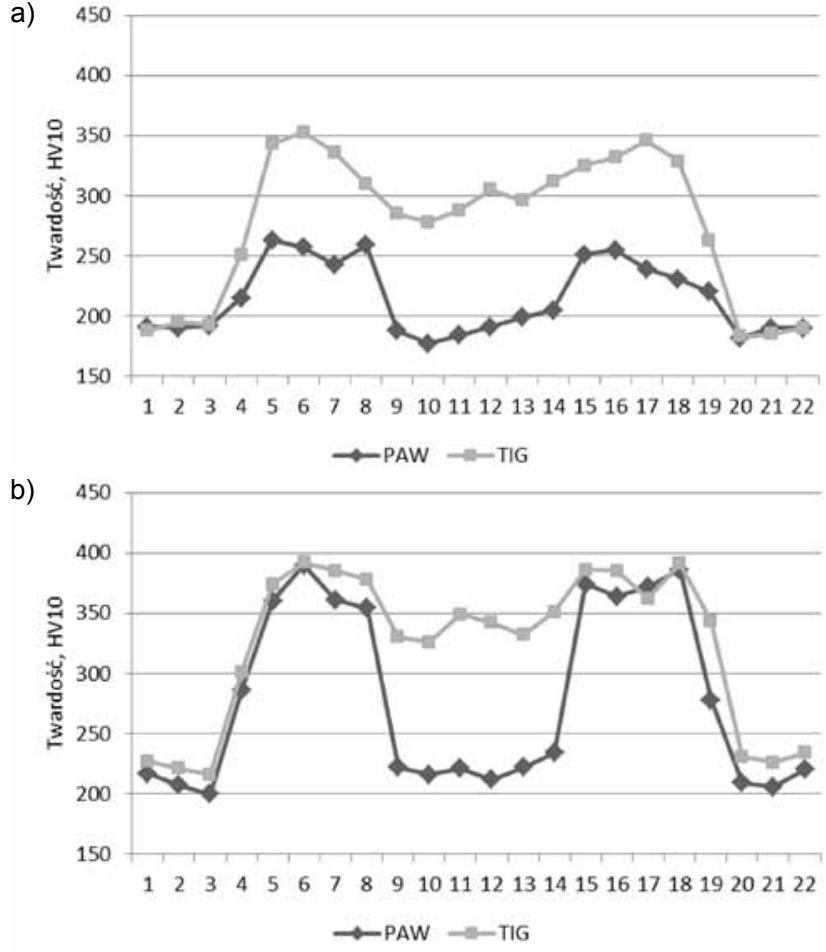

c)

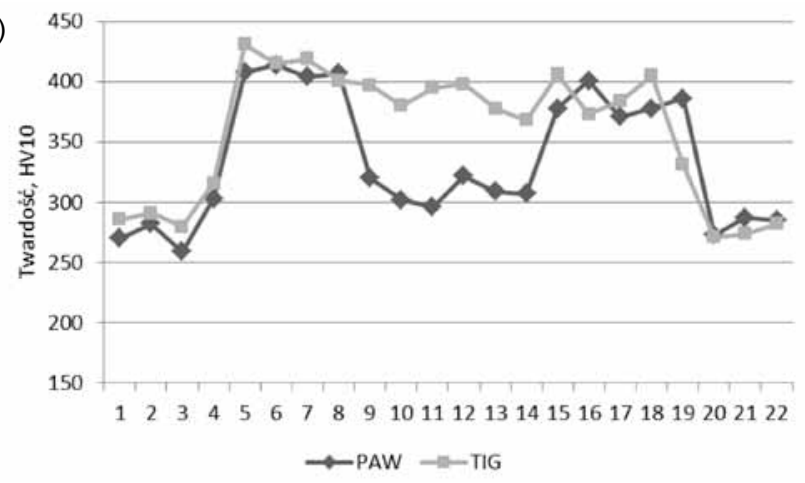

Rys. 14. Wyniki pomiarów twardości HV10 złączy spawanych a) ze stali Litec 600 DP, b) ze stali Litec 800 DP, c) ze stali Litec 1000 DP Fig. 14. Results of HV10 hardness measurement for welded joints of: a) Litec 600 DP steel, b) Litec 800 DP steel, c) Litec 1000 DP steel

wskazuje na konieczność zmniejszenia szybkości chłodzenia po spawaniu. Stal ta zawiera największą ilość mikrododatków stopowych, co może powodować podhartowania w strefie wpływu ciepła. Złącza wykonane metodą TIG charakteryzowały się wyższą twardością HV10 w spoinie niżeli spoiny w złączach wykonane metodą PAW. Zwiększona temperatura łuku plazmowego oraz koncentracja wiązki powoduje, że po spawaniu złącze stygnie z mniejszą prędkością niż w przypadku spawania TIG, gdzie występuje mniejsza gęstość energii (rys. 12).

\section{Podsumowanie}

Dwufazowe stale zaliczane do grupy stali o wysokiej wytrzymałości, mając wyższą granicę plastyczności od niestopowych stali konstrukcyjnych zwykłej jakości przeznaczonych do spawania, cechują się umiarkowaną wartością równoważnika węgla $C_{e}$, która może wskazywać na ich dobrą spawalność metalurgiczną.

Zastosowanie natężenia prądu spawania na poziomie $30 \div 35 \mathrm{~A}$ w metodzie TIG do łączenia blach ze stali DP o grubości $1,2 \mathrm{~mm}$ bez materiału 
dodatkowego umożliwia uzyskanie pełnego przetopu i wymaganej wartości umownej granicy plastyczności i wytrzymałości. Z kolei wysoka jakość stali DP (niska zawartość węgla, siarki i fosforu) ma wpływ na niską wadliwość złączy.

W strefie wpływu ciepła zaobserwowano wzrost twardości ponad $350 \mathrm{HV} 10$, nawet do $440 \mathrm{HV} 10$. Dopuszczalna graniczna wartość twardości w strefie wpływu ciepła złącza stali DP wg PN-EN 15614-1 [16] wynosi 450 HV. Zmniejszenie energii liniowej spawania powinno wpłynąć na ograniczenie tej wartości.

Wzrost objętości względnej martenzytu w strefie wpływu ciepła w wyniku spawania stanowiący przyczynę wzrostu twardości w mikroobszarach jest efektem małej pojemności cieplnej blach o niewielkiej grubości i przez to dużej prędkości chłodzenia złącza po spawaniu.

\section{Literatura}

[1] Baryliszyn P., Janus K., Noack T., Nowacki J.: Neuartiges Konzept zur Schweißparameterregelung beim widerstandspunktschweißen, Przegląd Spawalnictwa 11/2011, s 21-28.

[2] Bhadeshia H.K.D.H.: Application of Phase Transformation Theory to Welding, POSCO Lectures, 16th February 2008.

[3] Hofmann H., Mattissen D., Schaumann T. W.: Advanced cold rolled steels for automotive applications, Steel Research International, Issue 1/2009 717.

[4] Konspekt Ruukki, Welding of dual phase steels, 2012.

[5] Krajewski S., Nowacki J.: Modelowanie właściwości dwufazowych stali DP z zastosowaniem sztucznej inteligencji, Inżynieria Materiałowa 6/2012.

[6] Lis A.K., Gajda B.: Modeling of the DP and TRIP microstructure in the CMnAISi automotive steel, Journal of Achievements in Materials and Manufacturing Engineering, Vol. 15, Issue 1-2, 2006.

[7] Miernik K., Bogucki R., Pytel S.: Wpływ temperatury hartowania na mikrostrukturę i własności mechaniczne stali DP. Czasopismo Techniczne - Mechanika, (2-M/2009 Zeszyt 6), (2009).

[8] PN-EN 10346:2011 Wyroby płaskie stalowe powlekane ogniowo w sposób ciągły. Warunki techniczne dostawy.
[9] PN-EN 1321:2000 Spawalnictwo. Badania niszczące metalowych złaczy spawanych. Badania makroskopowe i mikroskopowe złączy spawanych.

[10] PN-EN 14175:2009 Materiały dodatkowe do spawania - Gazy i mieszany gazów do spawania i procesów pokrewnych.

[11] PN-EN 15614-1: Specyfikacja i kwalifikowanie technologii spawania metali. Badanie Technologii spawania. Część 1: Spawanie łukowe i gazowe stali oraz spawanie łukowe niklu i stopów niklu.

[12] PN-EN 571-1:1999 Badania nieniszczące - Badania penetracyjne - Zasady ogólne.

[13] PN-EN ISO 16834:2012 pt. Materiały dodatkowe do spawania - Druty elektrodowe, druty, pręty i stopiwa do spawania łukowego w osłonie gazu stali o wysokiej wytrzymałości - Klasyfikacja.

[14] PN-EN ISO 4136:2011 Badania niszczące złączy spawanych metali - Próba rozciągania próbek poprzecznych.

[15] PN-EN ISO 9015-2:2011 Badania niszczące złączy spawanych metali - Badanie twardości - Część 2: Badanie mikrotwardości złączy spawanych łukowo.

[16] Yi H. L., Lee K. Y., Bhadeshi H. K. D. H.: Stabilisation of ferrite in hot rolled $\delta$ - TRIP steel, Materials Science and Technology, Vol. 27, No. 2/2011 528.

\section{Podziękowanie}

Praca została zrealizowana w ramach poddziałania 8.2.2 „Regionalne Strategie Innowacji”, Działania 8.2 „Transfer wiedzy” Priorytet VIII „Regionalne Kadry Gospodarki” POKL woj. lubuskie „Stypendia naukowe dla doktorantów kształcących się na kierunkach uznanych za szczególnie istotne z punktu widzenia rozwoju województwa lubuskiego".

\section{SpawnLيMITIMA \\ www.pspaw.ps.pl}

